\title{
R\&D IN POLAND: IS THE COUNTRY CLOSE TO A KNOWLEDGE-DRIVEN ECONOMY?
}

\author{
Dorota CHYBOWSKA, Leszek CHYBOWSKI \\ Maritime University of Szczecin \\ Valeri SOUCHKOV \\ University of Twente
}

\begin{abstract}
:
Poland has a strong ambition to evolve rapidly into a knowledge-driven economy. Since 2004, it has been the largest beneficiary of European Union cohesion policy funds among all member states. Between 2007 and 2013, Poland was allocated approximately EUR 67 billion, whereas for 2014-2020 the EU budget earmarked EUR 82.5 billion for Polish cohesion policy. This means that in the coming years, Poland's R\&D intensity will grow. But the question remains: is 27 years of free market economy enough to enable a country's economy to become knowledge-based ? This paper offers an analysis of Polish R\&D expenditures and investments in terms of their sources (business, government or higher education sectors), types (European Union or state aid) and areas of support (infrastructure, education or innovation). It also characterises the Polish R\&D market with its strengths and weaknesses. Then, it examines the process of technology transfer in Poland, comparing it to best practice. Finally, the paper lays out the barriers to effective commercialisation that need to be overcome, and attempts to answer the question raised in its title.
\end{abstract}

Key words: commercialisation, Poland, R\&D market, knowledge-driven economy, technology transfer

\section{INTRODUCTION}

While the world was undergoing technological revolutions, Poland was fighting for freedom: for the right of its people to live with dignity, express their thoughts, develop and contact countries outside the Eastern Bloc. In 1970 IBM filed a patent application for a floppy disc [7]; in Poland in December of the same year the militia and the army were breaking the strikes of Polish workers. In 1981 the first space-rated orbiter Columbia was built in the USA [10], while in Poland martial law was enforced. In 1989 the Polish people were the first nation in the world to overthrow communist rule.

In fact, the 20th century was littered with historical events that directly impacted the Polish economy. Poland was able to resurface after the destruction of the First World War, and during the inter-war period was among the top 10 patent applicants in Europe. The Second World War interrupted its development, but despite what then followed, it would not be fair to say that between 1945 and 1989 Poland performed poorly, did not invent or make developments [20]. In this period, for instance, the Melex electric golf cart left the factory (1971) to become popular among players around the globe [17], and a team of scientists created the K-202 computer (1970-73) [29]. However, the majority of inventions and cutting-edge ideas were never introduced in Poland because of the political system and budget deficits, or were introduced elsewhere by Polish inventors for the benefit of other, already blooming economies. The route to a knowledge-driven economy was pro- longed for former Eastern Bloc countries, Poland included, as shown by patent statistics for the last decade [6].

The year 2016 is the 27th year of the free market economy in Poland. In 2004 Poland became a member of the European Union and the greatest beneficiary of its structural funds [21]: between 2007 and 2013 Poland was allocated approximately EUR 67 billion whereas for 2014-2020 the EU budget earmarked EUR 82.5 billion for its cohesion policy.

A standard definition of a knowledge-driven economy and metrics to gauge the dependence of societies on knowledge production have still been agreed [15, 24]. Different measures used for the same performance indicators and having different weights can result in many different rankings $[4,8,14]$. It is therefore problematic to refer to these measures and to attempt to determine the position of knowledge for Polish economy in 2016 on this basis. However, there is the Innovation Union Scoreboard, an instrument of the European Commission to assess the innovation performance of the EU Member States; this is the best alternative available at present.

Figure 1 presents the Summary Innovation Index for Poland for the period 2007-2014. Despite the EU allocations, Poland has still performed significantly below the EU28 average although it has shown a minimal upward trend (in 2007 the SII for Poland was 0.27, while in 2014 it was 0.313).

Figure 2, taken from [28] and prepared as a result of former research conducted by $[9,23,26]$, illustrates key factors of different economic models. Based on this analy- 


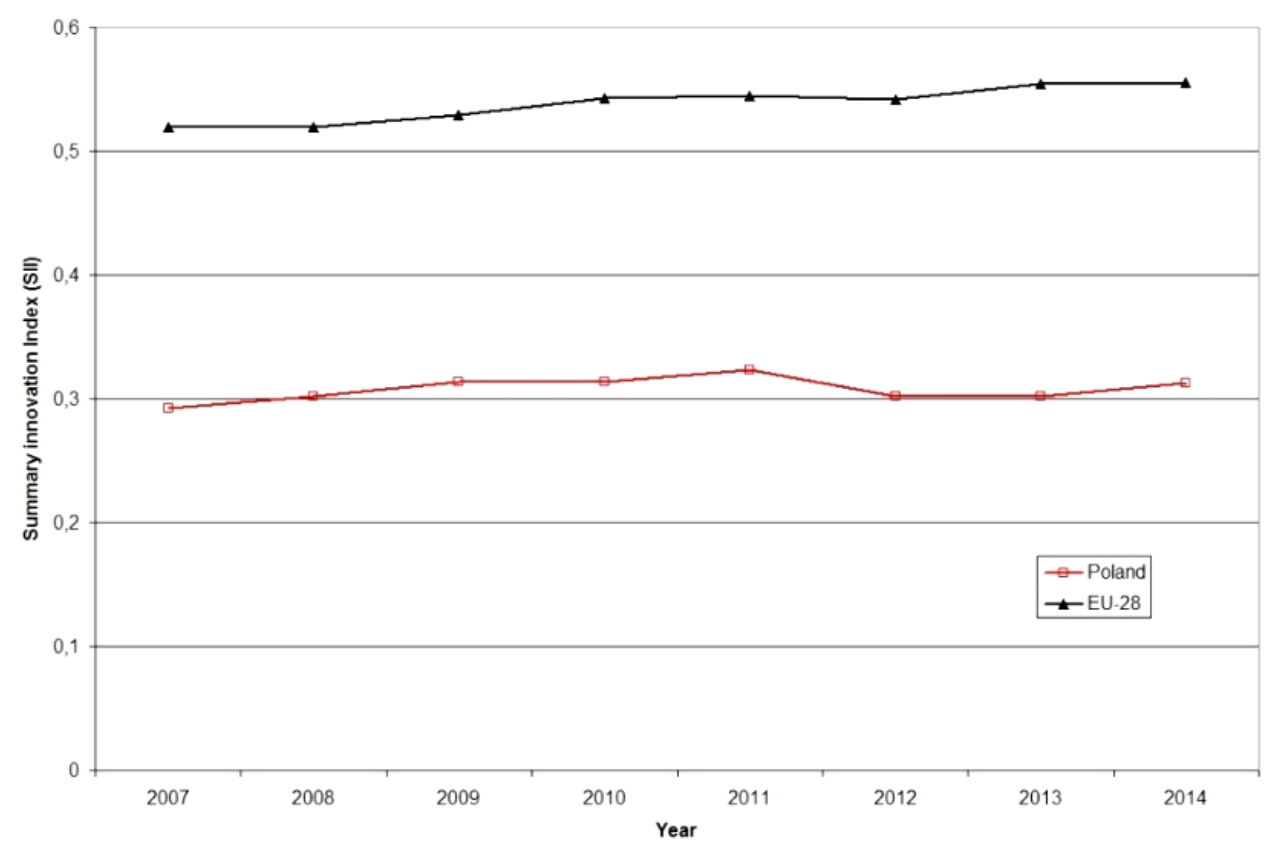

Fig. 1 Summary Innovation Index (SII) time series for Poland and EU-28 according to the Innovation Union Scoreboard 2015 methodology Source: Authors' analysis based on [11].

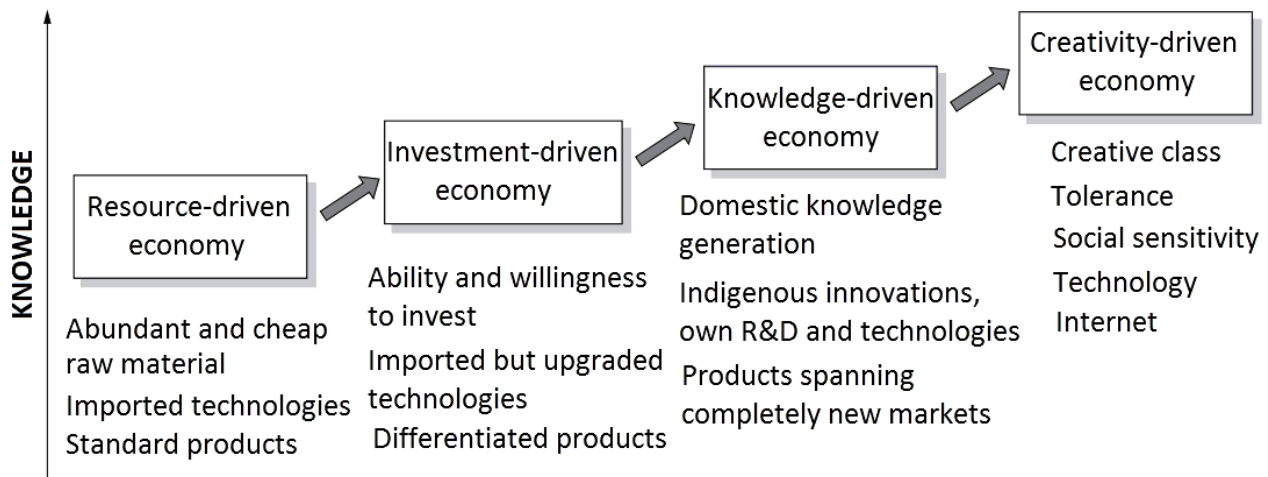

African countries

Poland, Czechia etc. Scandinavian countries Selected US and EU states

Fig. 2 Key factors of economic development

Source: [28].

sis, in order to rely on knowledge as its main asset and avoid the middle income trap, the Polish economy must be in possession of domestic knowledge resources $[1,2,5,18$, 30], its own, developed, R\&D facilities and technologies and products able to enter many markets.

In this paper, we provide an overview of the Polish R\&D market; we describe the expenses and investments incurred by different sectors for R\&D in recent years; we make an attempt to identify barriers to effective commercialisation of research results by presenting current stages of R\&D projects in Poland; and we outline the EU structural funds and Polish funding schemes for the growth of Polish entrepreneurs' innovation and commercialisation of research results. We also search for the main causes of Poland's unsatisfactory performance in innovation $[16,27]$.

\section{THE POLISH R\&D MARKET}

The Polish economy has strong GDP growth in relation to the EU average [19]. Polish R\&D intensities grew from 0.56 GDP (EUR 1,139 M) in 2004 to 0.94 GDP (EUR 3,864 M) in 2014 [3]. Over the same period, the level of interest of the commercial sector in innovation and commercialising research results has been very low [19]: private sector R\&D spend levels are several times lower than expected in terms of GDP growth (in [19] the cash flow for research from the private sector to universities and research institutes amounted to only $0.03 \%$ of GDP).

Supported by available reports [3] we contend that in Poland the governmental sector still has the largest share in the R\&D financing structure: in 2014 its share amounted to $45.2 \%$. The private sector's share rose up to $39.0 \%$ (by 14.6 percentage points in comparison to 2010). The research (educational) sector has invested the least in R\&D (2.2\%) [3]. As for internal R\&D expenses by sectors, the private sector spends most $-47.0 \%$ of turnover, followed by the research sector (29.0\%) and governmental (24.0\%). There were 153,500 R\&D personnel in 2014 [3]. For comparison, in the same year, there were $1,469,386$ Polish university graduates.

Polish enterprises, on the other hand, are more inclined to purchase ready-made technologies, mainly abroad, choosing to compete through low labour costs. 
SMEs comprise $99.8 \%$ of all Polish enterprises and employ $2 / 3$ of the labour force. Over $45.0 \%$ of them belong to the service sector while $30.0 \%$ are in wholesale and retail trades [12]. The structure of the Polish market is significant with reference to the EU co-funding streams, both in 20072013 and 2014-2020, summarised in Table 1 and Table 2 respectivly.

Table 1

Polish programmes co-funded by the European Union 2007-2013

\begin{tabular}{|c|c|c|c|}
\hline \multicolumn{4}{|c|}{ Financial Perspective 2007-2013 } \\
\hline Programme & Budget in billion EUR & & Purpose \\
\hline $\begin{array}{l}\text { Operational Programme } \\
\text { Innovative Economy (PO IG) }\end{array}$ & 8.7 & $\begin{array}{l}- \\
- \\
-\end{array}$ & $\begin{array}{l}\text { Innovations } \\
\text { New technologies } \\
\text { Research }\end{array}$ \\
\hline $\begin{array}{l}\text { Operational Programme } \\
\text { Infrastructure and Environment (PO liś) }\end{array}$ & 28.3 & - & $\begin{array}{l}\text { Environmentally friendly economy and sustainable } \\
\text { consumption of natural resources }\end{array}$ \\
\hline $\begin{array}{l}\text { Operational Programme } \\
\text { Human Capital (PO KL) }\end{array}$ & 10 & $\begin{array}{l}- \\
- \\
- \\
- \\
-\end{array}$ & $\begin{array}{l}\text { Employment increase } \\
\text { Social integration increase } \\
\text { Stimulating entrepreneurship } \\
\text { Education } \\
\text { Increasing the effectiveness of administration }\end{array}$ \\
\hline $\begin{array}{l}\text { Operational Programme } \\
\text { Development of Eastern Poland (PO PW) }\end{array}$ & 2.4 & $\begin{array}{l}- \\
- \\
-\end{array}$ & $\begin{array}{l}\text { Support for universities and science and technology } \\
\text { parks } \\
\text { Providing more efficient public transport } \\
\text { Broadband Internet access } \\
\text { Cycle lanes }\end{array}$ \\
\hline Regional Operational Programmes (RPO) & 17.3 & - & Social and economic development of Polish regions \\
\hline Technical Assistance & 0.5 & - & $\begin{array}{l}\text { Building the potential of public institutions distrib- } \\
\text { uting EU funds }\end{array}$ \\
\hline Total & 67.2 & & \\
\hline
\end{tabular}

Source: Authors' analysis.

Table 2

Polish programmes co-funded by the European Union 2014-2020

Financial Perspective 2014-2020

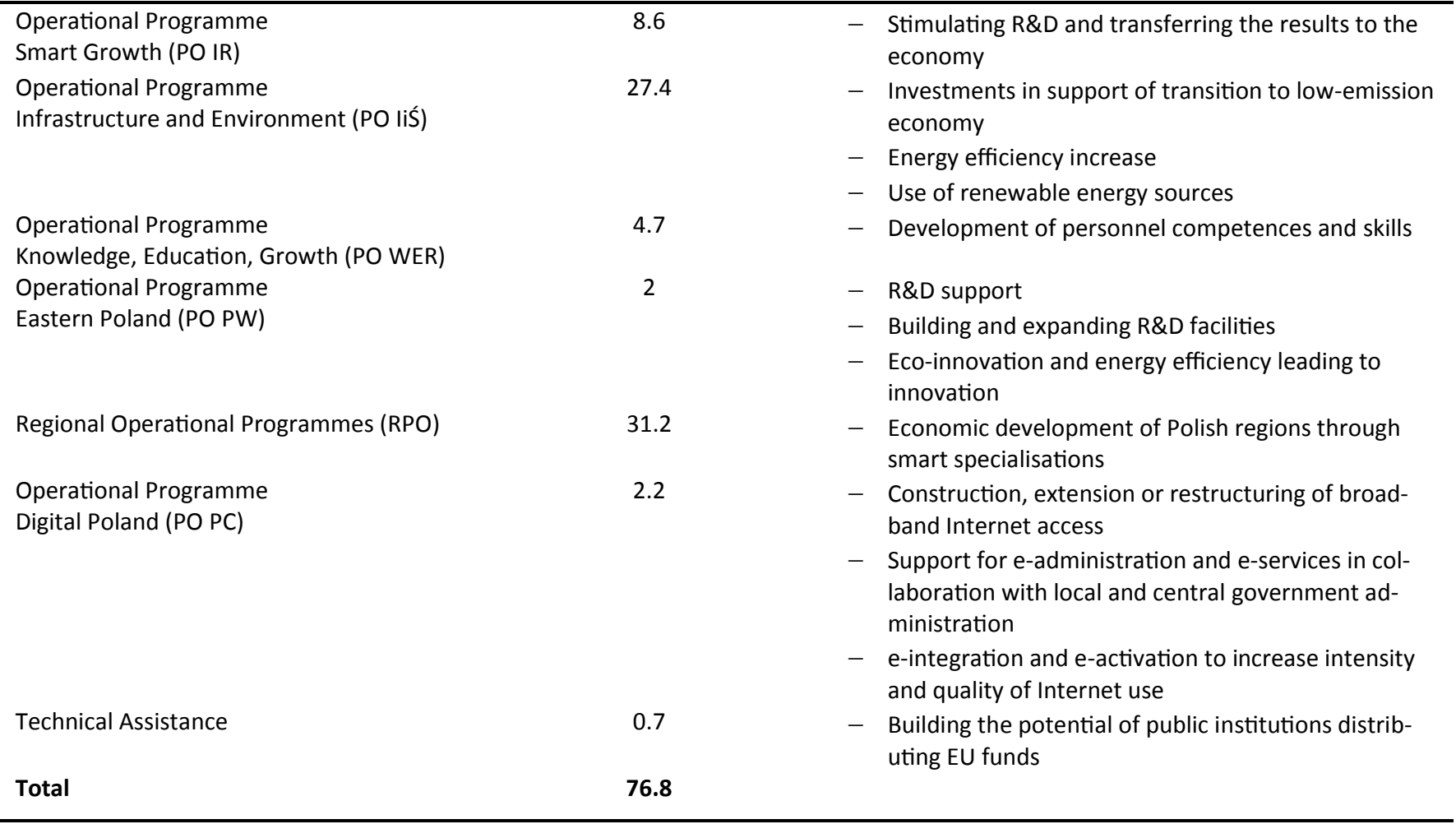

Source: Authors' analysis. 
In the period 2007-2013 (Table 1) most of the EU support was earmarked for infrastructure and environment, while in 2014-2020 (Table 2) Polish regions (voivodeships) will benefit from the greatest allocations, under the condition that they have identified and will strengthen their own key sectors of economy, the so called "smart specialisations". Poland's own contribution to this scheme equals $15 \%$.

In terms of the development of the Polish R\&D market through EU co-funding schemes, between 2007-2013 infrastructure investments had the greatest share, and the research sector (universities, research institutes) was their greatest beneficiary after enterprises. The period 20142020 shifts from this model, changing the rules of distribution. In a nutshell, enterprises become the focal point, but they are obliged to consume the financial support in order to innovate and introduce new products and services to the market. It is noteworthy that the support level amounts to $50.0 \%$ on average, meaning that enterprises must invest themselves. For comparison, in 2007-2013 the co-funding rates for enterprises amounted to $80.0 \% \mathrm{EU}$ on average. The financial perspective for 2014-2020 introduced a change for the research sector - it became a subcontractor and provider of (technological) solutions. Infrastructure investments are directed - i.e. enterprises build their own $R \& D$ facilities while universities (re-)build their R\&D facilities for the benefit of enterprises (or for their own benefit only if they are qualified for the Polish.

Roadmap for Research Infrastructures: to enter the list, universities must create consortia with others around given scientific areas which they are obliged to develop also by means of the EU structural funds to offer specialised services).

Pressure on the development of key Polish sectors through the EU co-funding schemes in the period 20142020 is visible at three levels. The first level are regions (voivodeships) which, following Table 2, distribute the funds to support their key sectors. The second, national, level reflects the sectors of the Polish economy from the point of view of global competition. The third level, intersectoral, supports key sectors of the Polish economy through R\&D activities conducted for their exclusive benefit. We refer here to initiatives like INNOLOT (aviation), INNOMED (medicine) or INNOTEXTILE (textile industry) launched by the National Centre for Research and Development.

Another type of incentive designed to boost the Polish R\&D market are "loans for technologies" granted to enterprises on a call-off basis. The grantee is obliged to introduce a technology, and in turn part of the loan is paid off through the EU co-funding scheme ("technological bonus"). $R \& D$ tax exemptions are also intended to induce the private sector to invest - entrepreneurs are allowed to decrease their tax base by the cost of new technology purchased from a Polish or foreign university or research institute (enterprises with the status of an R\&D centre included), not exceeding $50.0 \%$ in the case of SMEs and $30.0 \%$ for others. The R\&D expenses are tax deductible irrespective of the results of the R\&D activity [22].

\section{BARRIERS TO POLAND BECOMING A KNOWLEDGE-DRIVEN ECONOMY}

Ref. [19] specified the barriers facing the Polish R\&D market. They were divided into supply, demand and transmission mechanisms. We analysed the available data and mapped them to the barriers presented in [13], adding our own observations. The summary results are shown in Table 3.

The consequences arising from the barriers shown in Table 3 result in a lack of synchrony for joint activities undertaken by universities and businesses. Significant deficits in the process of commercialising research results in Poland might result from the business-academia relationship in terms of common R\&D projects presented in Figure 3.

Table 3

Barriers for the transition of the Polish economy into the knowledge-driven economy

\begin{tabular}{|c|c|c|}
\hline \multicolumn{2}{|l|}{ Item } & Barriers \\
\hline Demand & - & no interest of enterprises in innovation, \\
\hline & - & slow development of innovation culture and little experience in cooperation with universities, \\
\hline & - & decision centres located abroad in the case of the majority of large enterprises, \\
\hline & - & slow development of financial markets in terms of financing innovation, \\
\hline & - & $\begin{array}{l}\text { achieving good results of economic activity without the necessity to take the risk of introducing new technol- } \\
\text { ogies, }\end{array}$ \\
\hline & - & lack of "self-awareness" of Polish enterprises, \\
\hline & - & lack of knowledge on available home-made innovative technologies. \\
\hline \multirow[t]{7}{*}{ Supply } & - & little attraction of the demand, weak transmission mechanisms, lack of effective market regulation policy, \\
\hline & - & little or no interest of researchers in commercial aspects of R\&D, \\
\hline & - & lack of experience and skills to cooperate with business, \\
\hline & - & lack of expense and income settlement mechanisms at universities and research institutes, \\
\hline & - & tolerance for and availability of "soft" funding, lack of pressure on long term income from commercialisation, \\
\hline & - & decrease of human capital quality, \\
\hline & - & long time to reach research results by universities. \\
\hline \multirow{4}{*}{$\begin{array}{l}\text { Transmission } \\
\text { mechanisms }\end{array}$} & - & lack of market need for brokerage services, \\
\hline & - & lack of effective support of market regulation Policy, \\
\hline & - & unspecified competences of institutions participating in implementing the knowledge-driven economy, \\
\hline & - & inability of R\&D market actors to define their expectations towards each other. \\
\hline
\end{tabular}

Source: Authors' analysis. 
a)

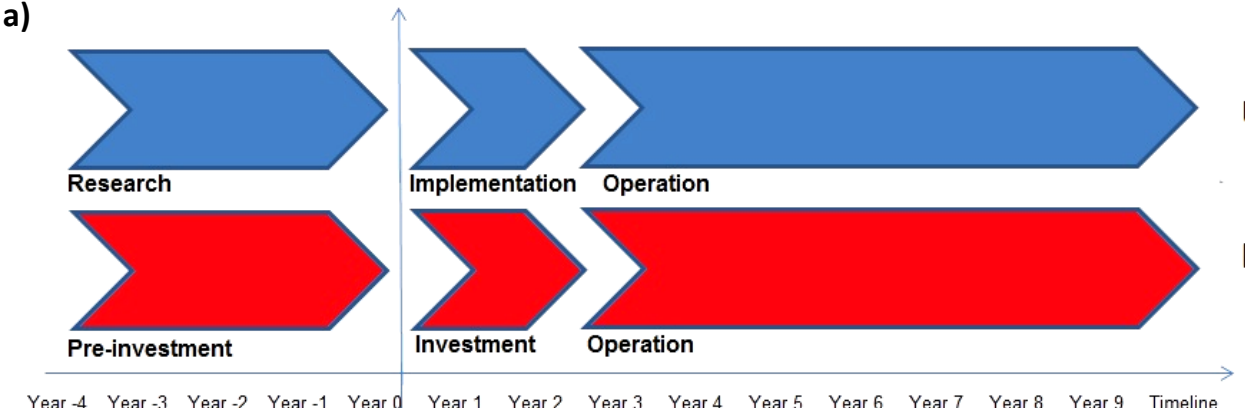

\section{UNIVERSITY}

ENTERPRISE

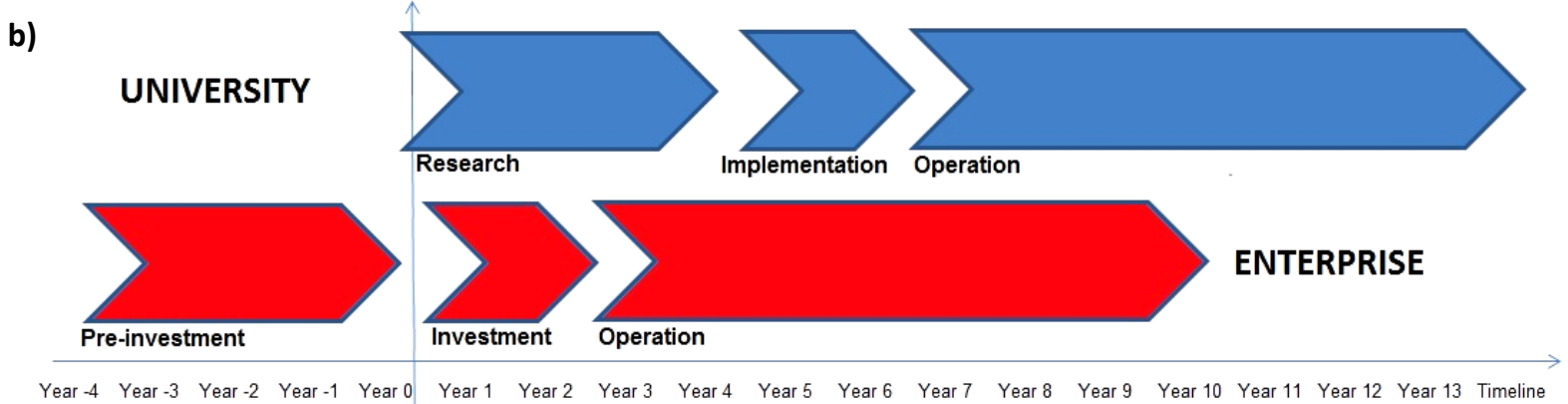

Fig. 1 Process of commercialising research results:

a) standard, typical for knowledge-driven economies, b) shifted, identifiable now in Poland

Source: Authors' analysis based on [25].

A good model of business-academia partnership is shown in Figure 3a, and this situation is typical for economies with a developed R\&D market. The enterprise and university go work hand in hand on a potential technology. For enterprises, the stage called "research stage" by universities is in fact pre-investment. From the point of view of a university, the second stage means prototyping and validating the prototypes to remove the faults unidentified at the research stage, while for enterprises it means investment. At the operational stage the technology enters the market. The whole process of translating research results into a product might take more than a decade.

The model presented in Figure $3 \mathrm{~b}$ reflects the current Polish situation for the main R\&D market actors. Because business-academia cooperation is disturbed, universities do not verify the utility of the research results they obtain with their potential receivers. This means that the receiver (enterprise) purchasing the research results must repeat the first stage (pre-investment) and the whole process lingers on. In other words, Polish universities make technologies first and then seek investors to go to market. Investors will not take the financial risk to invest in unproven technology thus, at best, will move back to the previous stage of pre-investment or, as is more common - withdraw.

\section{CONCLUSIONS}

Polish enterprises will receive meaningful financial support from the EU between 2014 and 2020, and the fact that they are obliged to co-invest will certainly ensure greater effectiveness of the spending. It is doubtful, however, if the EU funds earmarked for building R\&D facilities by the private sector will be consumed effectively taking into account the structure of the Polish market and the predominance of service sector SMEs.

Poland has started to polarise in terms of R\&D: the distance between Mazovian, Lesser Poland, Silesian, Lower Silesian, Greater Poland, Lodz and other Polish regions has increased. The governmental sector still has the largest share in the R\&D financing structure, so the R\&D market is not determined by free market mechanisms but by political decisions. Polish enterprises are still able to achieve economic benefits and compete through low labour costs without the necessity to invest in innovations. What is more, they are very likely to purchase the technology they need abroad, because it is proven and went through the stages shown in Figure 3 at someone else's risk.

The business-academia relationship for joint projects shown in Figure 3 leads us to the conclusion that in 2016 it is questionable if Poland has the knowledge, R\&D personnel and research results to meet the expectations of innovative enterprises. Polish universities and research institutes face the greatest challenge: because they are accustomed to the traditional model of state grants, they are rarely motivated to generate their income from commercialising $R \& D$ results which, as a matter of fact, do not meet the expectations of the private sector. On the other hand, EU funds are no substitute for a state innovation policy where the roles and expectations of each R\&D actor are precisely defined.

According to [15] the transition from an industrial economy to a knowledge-driven economy is characterised by:

1. Dematerialisation - transforming tangible assets into intangible assets that build the value of the enterprise; knowledge becomes the source of competitive advantage.

2. Dynamics - innovative rivalry, fast product generation and short life-cycles; imitation strategy replaced by the need for innovation.

3. Decentralisation - development of manufacturing networks and flexible business models.

4. Uncertainty (turbulent economy) - nothing is certain; a prosperous enterprise today might not exist tomorrow.

5. Globalisation - increase in market range (global village). 
Summarising, there are still many years of hard work and investments ahead if Poland is to make headway toward a knowledge-driven economy. The stage Poland is at now is mainly the consequence of the unfavourable historical events of the 20th century and the enormous destruction that followed. However, dynamic changes occurring in Poland in recent years at governmental, social and economic levels, as well as the support provided by the EU will certainly allow Poland to close the gap with other developed economies. A goal that Poland is very ambitious about.

\section{ACKNOWLEDGEMENTS}

This publication is financed through a research grants from the Ministry of Science and Higher Education of Poland 4/S/ITESO/14: "Diagnostics methods and efficient operation of complex technical systems in terms of failure prevention and environmental protection" and 1/S/IESO/17: "Increasing operational effectiveness of complex technical systems by systematic development and implementation of innovations using novel materials and modifying the object's structure".

\section{REFERENCES}

[1] J. Bartnicka, "Transfer of knowledge and innovations in shaping working conditions of disabled and elderly people", Scientific Journals of the Maritime University of Szczecin, vol. 103, no. 31, pp. 29-36, 2012.

[2] W. Biały, "Innovative solutions in the overhaul of the main fan of the ventillation system in a mine", Scientific Journals of the Maritime University of Szczecin, vol. 111, no. 39, pp. 25-30, 2014.

[3] Central Statistical Office, „Działalność badawcza i rozwojowa w Polsce w 2014 r.", Warszawa, Oct. 14, 2015.

[4] L. Chybowski, D. Idziaszczyk, B. Wiśnicki, "A Comparative Components Importance analysis of A Complex Technical System with The Use of Different Importance Measures", Systems Supporting Production Engineering. Review of Problems and Solutions, vol. 7, no. 1, pp. 23-33, 2014.

[5] L. Chybowski, D. Idziaszczyk, „O antropocentrycznym i technocentrycznym podejściu w procesie tworzenia innowacji", Systemy Wspomagania w Inżynierii Produkcji. Inżynieria Systemów Technicznych, vol. 11, no. 2, pp. 51-63, 2015.

[6] CRiDO Taxand, „Raport o stanie patentowania w Polsce. Patenty szansą na wzrost innowacyjności polskich przedsiębiorstw", Warszawa, May 28, 2015.

[7] G. Dalakov. (2017, Jun. 25). Floppy Disk [Online]. Available: http://history-computer.com/ModernComputer/ Basis/floppy_disk.html

[8] T. Hatzichronoglou, "Globalisation and Competitiveness: Relevant Indicators", OECD Science, Technology and Industry Working Papers, 1996/05, Paris: OECD Publishing, 1996.

[9] H. Hernesniemi, M. Lammi, P. Ylä-Anttila, "Advantage Finland: The Future of Finnish Industries", The Research Institute of the Finnish Economy, The Finnish National Fund for Research and Development, Helsinki: Taloustieto Oy, 1996.

[10] E. Howell. (2016, Jan. 16). Columbia: First Shuttle in space [Online]. Available: http:// www.space.com/18008-space-shuttle-columbia.html

[11] Innovation Union Scoreboard 2015, DirectorateGeneral for Internal Market, Industry, Entrepreneur- ship and SMEs (European Commission), Brussels, Belgium, 2015.

[12] D. Jegorow, A. Niedużak, Eds. Wpływ sektora $B+R$ na wzrost konkurencyjności polskiej gospodarki poprzez rozwój innowacyjności, vol. 2. Chełm: Chełmskie Stowarzyszenie Rozwoju Społeczno-Gospodarczego CIVIS, 2012.

[13] J. Kaźmierczak, „Innowacyjność: uwarunkowania i perspektywy w warunkach polskich", in Komputerowo Zintegrowane Zarzqdzanie, vol. 1, R. Knosala, Ed. Opole: Oficyna Wydawnicza Polskiego Towarzystwa Zarządzania Produkcją, 2009, pp. 481-492.

[14] A. Majchrowicz-Bączyk. (2017, Jun. 25). EU Funds in Poland 2014-2020 [Online]. Available: http:// roedl.com/pl/en/services/state_aid_advice/ eu_funds_in_poland_20142020.html

[15] M. Matusiak, K.B. Matusiak. (2017, Jun. 25). Słownik Innowacji - Leksykon haset [Online]. Available: http:// pi.gov.pl/parp/chapter_96055.asp? soid $=256993$ FED9734DD0B31A4785E53F81F5

[16] O. Mayer, "Flexible lighting distribution on "party ships", Scientific Journals of the Maritime University of Szczecin, vol. 121, no. 49, pp. 9-16, 2017.

[17] Melex website. (2017, Jun. 25). History [Online] Available: http://www.melex.com.pl/en/about-us/history

[18] M. Molenda, "Knowledge as a determinant in developing a quality management system", Scientific Journals of the Maritime University of Szczecin, vol. 111, no. 39, pp. 116-121, 2014.

[19] W.M. Orłowski, „Komercjalizacja badań naukowych w Polsce. Bariery i możliwości przełamania", PwC, Warszawa, Jul. 2013.

[20] Polish Patent Office website. (2017, Jun. 25). Kalendarium historyczne, lata 60-te i 70-te [Online]. Available: http://uprp.pl/lata-60-te-i-70-te/ Menu10,111,2,index,pl/

[21] Portal Funduszy Europejskich website. (2017, Nov. 30). [Online]. Available: https:// www.funduszeeuropejskie.gov.pl/strony/ofunduszach/raporty/raporty-sprawozdania/\#/ domyslne=1/

[22] Portal Innowacji website. (2017, Jun. 25). Rozwiqzania podatkowe wprowadzone Ustawq o niektórych formach wspierania działalności innowacyjnej [Online]. Available: http://www.pi.gov.pl/finanse/ chapter_95014.asp

[23] M.E. Porter, The Competitive Advantage of Nations. London: Macmillan, 1990.

[24] W.W. Powell, K. Snellman, "The Knowledge Economy", Annual Review of Sociology, vol. 30, pp. 199-220, 2004.

[25] A. Półkoszek, „Wycena technologii - materiały szkoleniowe", BOMIS, Poznań, 2017.

[26] J. Routi, "Research and development for knowledge economy", in Towards a New Creative and Innovative Europe, A. Kukliński, C. Lusiński, K. Pawłowski, Eds. Nowy Sącz: WSB-NLU, Oficyna Wydawniczą "Rewasz", 2007.

[27] V.V. Souchkov. (2017, Jul. 17). Psychological Barriers and Creativity [Online]. Available: http:// www.xtriz.com/ Souchkov_PsychologicalBarriersAndCreativity.pdf 
[28] A. Świda, „Kreatywność w gospodarce”, in Kształtowanie zachowań innowacyjnych, przedsiębiorczych $i$ twórczych w edukacji inżyniera, J. Skonieczny, Ed. Wrocław: Wydawnictwo Indygo Zahir Media, 2011, pp. 25-36.

\section{mgr Dorota Chybowska}

Maritime University of Szczecin, Technology Transfer Office ul. Wały Chrobrego 1-2, 70-500 Szczecin, POLAND

e-mail: d.chybowska@am.szczecin.pl

dr hab. inż. Leszek Chybowski, prof. AM

Maritime University of Szczecin

Faculty of Marine Engineering,

ul. Wały Chrobrego1-2, 70-500 Szczecin, POLAND

e-mail: I.chybowski@am.szczecin.pl

\section{Valeri Souchkov, MSc}

University of Twente, Faculty of Engineering Technology

Drienerlolaan 5, 7522 NB Enschede, NEDERLANDS

e-mail: valeri@xtriz.com
[29] Wikipedia website. (2017, Jun. 25). K-202 [Online]. Available: https://pl.wikipedia.org/wiki/K-202

[30] R. Wolniak, "Innovation in the context of economic situation in the EU countries", Scientific Journals of the Maritime University of Szczecin, vol. 96, no. 24, pp. 141-147, 2010. 